\title{
Karbon Aktif Tempurung Kelapa untuk Peningkatan Kualitas Air Tambak
}

\author{
Chrisna Adhi Suryono*, Irwani, Suryono, Endang Sri Susilo, Subagiyo dan Sugeng \\ Widada
}

\author{
Departemen IImu Kelautan, Fakultas Perikanan dan IImu Kelautan, Universitas Diponegoro \\ Jl. Prof. Soedarto, SH. Tembalang, Semarang 50275 \\ Email : chrisna_as@yahoo.com
}

\section{Abstract \\ Carbon Active from Coconut Shell as Tambak Water Quality Increasing}

The negative impact in intensive cultivation of prawn is the decreasing water quality, caused by the toxic material from food and prawn faces. One alternative to solve that problem is to use the active carbon from coconut shell as adsorbent of toxic material.The aim of these activities is to inform to teach how was adsorption toxic compound by using active carbon running well. The result showed, concentration of $\mathrm{H}_{2} \mathrm{~S}$ in the water dramatically decrease until $0.02 \mathrm{ppm}$ and $\mathrm{NH}_{3}$ until $0.05 \mathrm{ppm}$ and $\mathrm{NO}_{2}$ 0,05 ppm. That condition indicates, it was good condition for prawn to life. The conclusion of this public service activity was active carbon from coconut shell can be reduce toxic material and all participant in training very interested approximately $95 \%$ of material of training has been understood.

Keywords: Carbon active, coconut shell, $\mathrm{H}_{2} \mathrm{~S}, \mathrm{NH}_{3}, \mathrm{NO}_{2}$

\begin{abstract}
Abstrak
Dampak negatif dari budidaya udang secara intensif adalah menurunnya kualitas air tambak karena menumpuknya zat zat beracun yang berasal dari akumulasi sisa pakan maupun kotoran udang. Salah satu alternatif pengendalian kualitas air tambak akibat permasalahan tersebut dengan menggunakan karbon aktif dari tempurung kelapa sebagai bahan absorban. Tujuan dari pengabdian masyarakat adalah untuk memberikan percontohan dan pelatihan kepada petani tambak tentang pemanfaatan arang tempurung kelapa sebagai bahan absorban alami yang berguna meningkatkan kualitas air tambak. Hasil kegiatan yang telah dilakukan meliputi peyuluhan dan percontohan menunjukan 95\% masyarakat memahami materi yang diberikan selama penyuluhan. Hal tersebut terlihat dari respon masyarakat dalam bentuk tanya jawab. Sedangkan hasil nyata dari penggunaan arang tempurung kelapa menunjukan kandungan $\mathrm{H}_{2} \mathrm{~S} \quad 0,02 \mathrm{ppm}, \mathrm{NH}_{3} \quad 0,05 \mathrm{ppm}$ dan $\mathrm{NO}_{2} \quad 0,05 \mathrm{ppm}$. Kandungan zat zat tersebut menunjukan kondisi yang baik untuk hidupnya udang.
\end{abstract}

Kata Kunci: Karbon aktif, tempurung kelapa, $\mathrm{H}_{2} \mathrm{~S}, \mathrm{NH}_{3}, \mathrm{NO}_{2}$

\section{PENDAHULUAN}

Karbon aktif sering juga disebut sebagai arang aktif, adalah suatu jenis karbon yang memiliki luas permukaanyang sangat besar karena melalui proses aktivasi. Sedangkan karbon sendiri memiliki bentuk amorf dan banyak ditemukan dari berbagai bahan utama, antara lain batubara, tempurung kelapa, limbah industri, kayu, biji aprikot, kulit singkong, dan kulit kemiri (Hartati et al., 2013). Indonesia merupakan salah satu negara yang memiliki potensi besar pengembangan karbon aktip dari bahan tempurung kelapa. Produksi arang tempurung kelapa di Indonesia sebesar 66,200 ton/tahun terutama 
dari beberapa daerah di Indonesia bagian timur (Chemviron, 2015). Sumber arang aktif di Indonesia sebenarnya tidak hanya dari tempurung kelapa namun masih banyak bahan lain yang dapat digunakan seperti tempurung kemiri, limbah sawet, bahan tambang, kayu atau limbah kayu, gambut, hasil pertanian dan limbah peternakan (Arsad dan Hamdi, 2010). Karbon aktif dapat dikatakan "material of the future" karena dapat dikatakan sebagai material dengan banyak fungsi karena manfaat yang sempurpurna untuk dalam berbagai proses penjernihan/ pemulihan/ penyehatan material termasik air (Sirichote et al., 2002), penurunan kadar cafein pada kopi (Marsh and Rodriguez-Reinoso, 2006), penyaringan warna (Li et al., 2015), penghilanga aroma atau bau pada udara (Sahu et al., 2010), pengolahan air minum (Jeswani et al., 2015; Subha and Namasivayam, 2009), industi gas dan pembersihan pendingin udara (Arena, N. et al., 2016). Sebenarnya manfaat karbon aktif dalam air tidak hanya untuk keperluan air minum namun jaga dapat digunakan untuk penyehatan air seperti penyerapan logam berat $(\mathrm{Pb}, \mathrm{Fe}$ dan $\mathrm{Cu})$, maupun Nitrit dan Phenol (Arsad dan Hamdi, 2010).

Kemunculan penyakit erat kaitannya dengan penurunan mutu air tambak yang disebabkan oleh akumulasi sisa pakan serta sisa metabolisme. Guna mengatasi penurunan kualitas air tambak dapat digunakan bahan bahan penjernih air seperti Zeolit, $\mathrm{MnO} 4$ dan bahan bahan kimia lainnya. Bahan bahan ini diharapkan dapat mereduksi bahan-bahan beracun sehingga bahan toksik seperti amoniak $\left(\mathrm{NH}_{3}\right)$ dan nitrit
$\left(\mathrm{NO}_{2}\right)$ yang terakumulasi dalam air tambak konsentrasinya dapat menurun. Namun diketahui zeolit kurang efektif untuk memperbaiki mutu air tambak disamping itu harganya cukup mahal (Cholik, 1988). Oleh karena itu perlu dicari bahan alternatif untuk menggantikan zeolit. Bahan yang mempunyai kemiripan dengan zeolit adalah karbon aktif. Dari kemampuan arang aktif yang mampu menyerap gas gas yang terlarut dalam air, logam berat maupun warna dan bau memungkinkan arang aktif tersebut dimanfaatkan dalam pengolahan air tambak tambak. Maka dari itu tujuan dari kegiatan plait research (pengabdian) untuk mengetahui potensi atau kemampuan arang aktif dalam peningkatan kualitas air tambak.

\section{MATERI DAN METODE}

Materi yang digunakan dalam plait research yang merupakan bagian dari pengabdian masyarakat adalah arang aktif dari tempurung kelapa yang dibeli dari pasaran. Arang aktif yang digunakan dibungkus dalam jaring kemudian diletakkan dalam pintu pemasukan air tambak tamnbak sehingga air yang akan masuk kedalam tambak dapat tersaring oleh oleh karbon aktif.

Parameter yang diamati untuk mengetahui kualitas air tambak adalah $\mathrm{H}_{2} \mathrm{~S}$, $\mathrm{NH}_{3}$ dan $\mathrm{NO}_{2}$. Pengukuran dilakukan dengan Water Guality Cheker (Horiba) pada saat ail sebelum melewati pintu tambak dan setelah melewati pintu tambak. Kegiatan ini dilakukan di pertambakan Kecamatan Sayung, Kabupaten Demak.

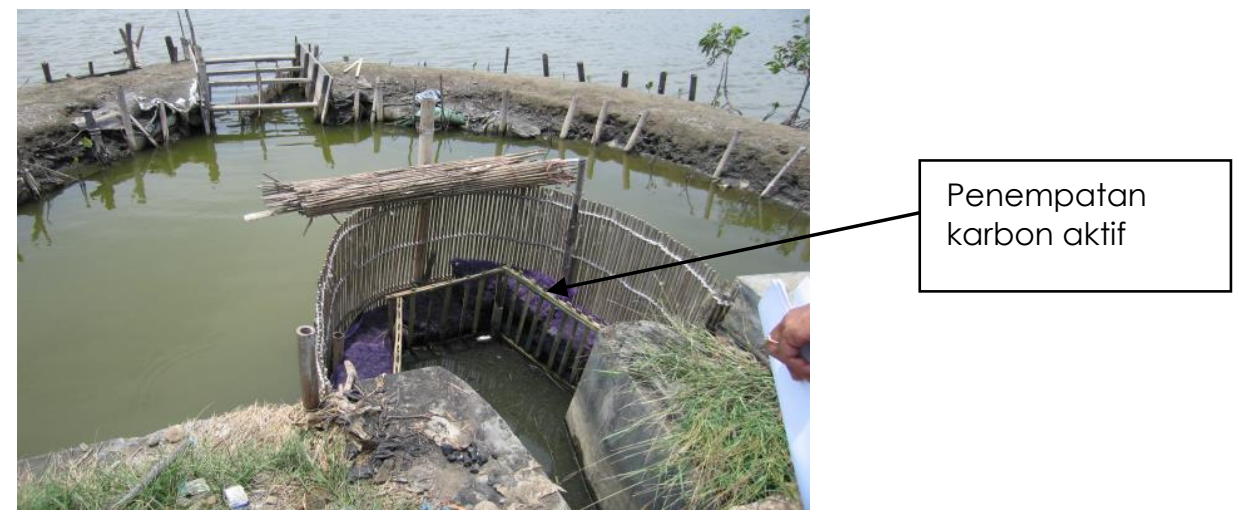

Gambar 1. Penempatan karbon aktip pada pintu tambak 


\section{HASIL DAN PEMBAHASAN}

Hasil kegiatan pengunaan karbon aktif untuk menyaring air tambak yang dilakukan dipertambakan Desa Muara Reja Tegal menunjukan konsentrasi $\mathrm{H} 2 \mathrm{~S}, \mathrm{NH} 3$ dan $\mathrm{NO} 2$ menurun setelah mengalami proses pentaringan (Tabel 1). Perbedaan konsentrasi $\mathrm{H} 2 \mathrm{~S}$, NH3 dan NO2 yang sangat $(\mathrm{p} \leq 0,05)$ sebelum dan setelah penyaringan air tambak, membukikan bahwa karbon aktif yang memiliki pori pori sangat tinggi berkisar antara 100 sampai dengan $2000 \mathrm{~m}^{2} / \mathrm{g}$ mampu menyaring/ mengakumulasi senyawa yang ada dalam air tambak. Tingginya pori pori karbon aktif tersebut dapat mengabsobsi senyawa yang mengandung $\mathrm{N}$ dan $\mathrm{CO} 2$ senggingga sangat baik untuk perairan (Borghei et al, 2017). nyata perbedaan yang terlarut dalam air tambak

Tabel 1. Hasil pengukuran senyawa terlarut dalam air tambak sebelum dan setelah penyaringan dengan karbon aktif

\begin{tabular}{cccc}
\hline $\begin{array}{c}\text { Senyawa } \\
\text { dalam air } \\
\text { tambak }\end{array}$ & $\begin{array}{c}\text { Sebelum } \\
\text { (ppm) }\end{array}$ & $\begin{array}{c}\text { Sesudah } \\
\text { (ppm) }\end{array}$ & $\begin{array}{c}\text { Syarat } \\
\text { Untuk } \\
\text { Tambak } \\
\text { Udang } \\
\text { (ppm) }\end{array}$ \\
\hline $\mathrm{H}_{2} \mathrm{~S}$ & 0,07 & 0,02 & $\geq 0,1$ \\
$\mathrm{NH}_{3}$ & 0,25 & 0,05 & $\geq 0,5$ \\
$\mathrm{NO}_{2}$ & 0,31 & 0,05 & $\geq 0,5$ \\
\hline
\end{tabular}

Hasil filtrasi selama kegiatan menunjukan bahwa kandungan kandungan $\mathrm{H}_{2} \mathrm{~S}$ sebesar 0,02 ppm kondisi ini adalah kondisi yang baik karena untuk pesyaratan udang dengan baik tidak diperkenankan melebihi 0,1 ppm (Denila, 1977). Sedangkan kandungan Amonia $\left(\mathrm{NH}_{3}\right)$ dan Nitrit $\left(\mathrm{NO}_{2}\right)$ menunjukan kandungan dibawah 0,05 ppm hal ini tentunya sangat baik karena untuk pesyaratan udang hidup dengan baik ditambak tidak diperkenankan melebihi 0,5 ppm (Denila, 1977). Keberadaan unsur unsur yang berbahaya tersebut dalam tambak sebagian besar dihasilkan dari pembusukan bahan organik baik itu yang berasal dari limbah tambak seperti sisa pakan udang atau kotoran udang yang membusuk atau dari luar perairan tambak (Potter, 1977). Lebih lanjut Kaul (1987) menyatakan bahwa bahan beracun seperti amoniak, nitrit dan nitrogen sulfida dapat diadsorpsi oleh karbon aktif, sedangkan arang tempurung kelapa merupakan salah satu bahan pembuat arang aktif. Suryono et al., (2001) juga telah melakukan penggunaan karbon dari arang tempurung kelapa untuk menurunkan ammonia dan $\mathrm{H}_{2} \mathrm{~S}$ di pertambakan Desa Patebon Kendal. Keseluruhan hasil kegiatan pengabdian masyarakat diatas dapat dikatan berhasil karena kualitas air tambak dapat ditingkatkan terbukti dengan rendahnya kandungan bahan bahan yang mengganggu tersebut dibawah ambang yang tidak disyaratkan.

\section{UCAPAN TERIMAKASIH}

Pada kesempatan ini kami mengucapkan terimasih atas pendanaan melalui BOPTN FPIK 2017 karena artikel ini merupakan bagian dari kegiatan pengabdian masyarakat dengan judul "Aplikasi Karbon Aktif dari Limbah Kelapa untuk Peningkatan Kualitas Air Tambak Guna Peningkatan Produksi di Kecamatan Sayung, Kabupaten Demak"

\section{DAFTAR PUSTAKA}

Arena, N., Lee, J. \& Clift, R., 2016., Life Cycle Assessment of activated carbon production from coconut shells. J. Clean. Prod. 125:68-77

Arsad, E. \& Hamdi, S., 2010., Teknogogi pengolahan dan pemenfatan karbon aktif untuk industri. J. Riset Industri Hasil Hutan. 2, (2):43- 51

Borghei, M., Laocharoen, N., KibenaPõldsepp, E., Leena-Sisko, J., Campbell, J., Kauppinen, E., Tammeveski, K., \& Rojas, O.J., 2017. Porous N,P-doped carbon from coconut shells with high electrocatalytic activity for oxygen reduction: Alternative to Pt-C for alkaline fuel cells. App. Catal. B. Environ. 204:394 402

Cholik, F. 1988. Manfaat pengelolaan tanah dasar, padat penebaran, penggunaan alat bantu bahan penjernih air dalam pengelolaan tambak intensif. Makalah pada pameran industri perikanan Indonesia 1988. Jakarta, 21 hal.

Denila, L. 1977. Conditioning of fishponds. Reading on Aquaculture Practices. 
SEAFDEC Aquaculture Department, lloilo, $87-89 \mathrm{pp}$.

Hartati, R., Allwar. \& Fitri, N., 2013. Karakterisasi dan modifikasi karbon aktif tempurung kelapa sawit dengan asam nitrat untuk menyerap logam besi dan tembaga dalam minyak nilam. Ind. J. Chem. Res. 2 (1):74- 83

Jeswani, H.K., Gujba, H., Brown, N.W., \& Roberts, E.P.L., Azapagic, A., 2015. Removal of organic compounds from water: life cycle environmental impacts and economic costs of the Arvia process compared to granulated activated carbon. J. Clean. Prod. 89:203e213. DOI : 10.1016/j.jclepro.2014.11.017.

Kaul, B.K. 1987. Adsorption equilibrium data. Hand book. Ind Eng.Chem Res. 26. 928, p. $305-324$.

Li, Q., Qi, Y., \& Gao, C., 2015. Chemical regeneration of spent powdered activated carbon used in decolorization of sodium salicylate for the pharmaceutical industry. J. Clean. Prod. 86, 424-431.

Marsh, H. \& Rodriguez-Reinoso, F., 2006. Activated Carbon, second ed. Ntuli, V., Hapazari, I., 2013. Sustainable waste management by production of activated carbon from agroforestry residues. South Afr. J. Sci. 109:1077-1082. DOI : 10.1590/ sajs.2013/1077.
Potter, T. 1977. The problems to fish culture associated with acid sulfate and method for their improvement. 12 th Ann. Nat. Conf. of the Philippines. Fed. of Fishfarm Product. $15 \mathrm{pp}$.

Sahu, J.N., Acharya, J., Meikap, B.C., 2010. Optimization of production conditions for activated carbons from Tamarind wood by zinc chloride using response surface methodology. Bioresour. Technol. 101:1974-1982. DOI : 10.1016/j.biortech. 2009.10.031.

Sirichote, O., Innajitara, W., Chuenchom, L., Chunchit, D., Naweekan, K., 2002. Adsorption of iron (III) ion on activated carbons obtained from bagasse, pericarp of rubber fruit and coconut shell. J. Sci. Technol. 24:235-242.

Subha, R., Namasivayam, C., 2009. Zinc chloride activated coir pith carbon as low cost adsorbent for removal of 2,4dichlorophenol: equilibrium and kinetic studies. Indian J. Chem. Technol. 16:471479.

Suryono, C.A, Irwani, Djunaedi. A., 2001. Percontohan dan pelatihan pemanfaatan arang tempurung kelapa sebagai upaya pengendalian kualitas air tambak guna peningkatan produksi udang windu Penaeus monodon Fab di Kecamatan Patebon Kendal. Info. 4(1): 55-58 